\title{
BOW VECTOR RIGIDITY CONCEPTION FOR SHIPS WHEN COLLISION
}

\author{
КОНЦЕПЦІЯ ВЕКТОРНОЇ ЖОРСТКОСТІ \\ НОСОВИХ КІНЦЕВОСТЕЙ СУДЕН ПРИ ЗІТКНЕННЯХ
}

\author{
Borys N. Mykhaylov \\ borys.mykhailov@nuos.edu.ua \\ ORCID: 0000-0002-9087-9906
}

\author{
Б. М. Михайлов, \\ канд. техн. наук, доцент
}

\author{
Admiral Makarov National University of Shipbuilding, Mykolaiv \\ Національний університет кораблебудування імені адмірала Макарова, м. Миколаӥв
}

\begin{abstract}
The humanity of world society demands more safety in all spheres of activity including sea transport. So the vessel safety when collision is very important. This work is devoted to the problem of construction safety when collision. There are presented the results of energy consuming bow devise when collision computer preliminary calculations with the help of Finite Element Method program and a base formula to calculate an energy capacity of such a devise. Object of research - is an energy consuming bow devise when collision that not only consume own energy when destruction, but increase the total area of contact aboard the rammed vessel and energy dispersion due to increase of strike time. The actuality of this research direction - construction safety of ships when collision is conditioned by the big annual losses because of this kind of damages. Every year as a rule more then twenty significant size vessels are lost and dozens have the hard damages because of this kind of accidents that lead to tremendous moral, economic and ecology damages. The usage of vector rigidity conception and offered energy consuming devise for transport vessels bow parts when the contact at collision has started not with the solid bulb underwater structure of ram vessel but with heir forepeak and forecastle constructions (over the water surface) that should be destroyed firstly and consume the certain amount of total strike energy when collision and to increase vessels safety when collision. That conceptions can be used to increase construction safety of transport vessels when collision for new designed ones and for modernization of existing ones.
\end{abstract}

Purpose. Increase of construction safety of transport vessels when collision on the base of using vector rigidity conception and an offered energy consuming bow devise.

Method. Analytical, numerical.

Results. There were presented the analytical formula to evaluate the destruction energy of offered bow device and its computer calculation results for a certain example.

Scientific novelty. There were offered the new directions of construction safety development when collision.

Practical importance. Application of the results in practice could increase construction safety of ships when collision. Key words: ship; bow; construction defense; collision; energy consuming devise.

Анотація. Гуманність світової спільноти вимагає більше безпеки в усіх сферах діяльності, включаючи морський транспорт, тому безпека суден при зіткненнях дуже важлива. Робота присвячена актуальній проблемі конструктивного забезпечення підвищення безпеки суден при зіткненнях. Наведено результати розрахунків запропонованого носового енергопоглинального пристрою за спеціалізованою програмою на базі МКЕ, а також базову аналітичну залежність для розрахунку енергоємності такого пристрою в разі зіткнення суден. Об'єкт дослідження - носовий енергопоглинальний пристрій транспортних суден, який в разі зіткнень не лише поглинає енергію при власному руйнуванні, а й збільшує площу контактної плями на борту протараненого судна і розсіювання енергії завдяки тривалості часу удару. Актуальність тематики безпеки суден при зіткненнях зумовлена великими щорічними втратами за таких видів аварій. Щороку при зіткненнях гинуть понад 20 великих суден і десятки отримують серйозні пошкодження, завдаючи таким чином величезну моральну, економічну та екологічну шкоду.

Використання такого пристрою і принципу векторної жорсткості для носової кінцевості суден, коли контакт при зіткненні починається не $з$ жорсткого бульба судна, що таранить, а з руйнування надводної частини носової кінцевості, може істотно підвищити безпеку суден при зіткненнях - їх конструктивну безпеку, і використовуватися в практиці суднобудування під час проєктування і модернізації суден. 
Мета. Збільшення конструктивної безпеки транспортних суден при зіткненнях на основі використання концепції векторної жорсткості та запропонованого енергопоглинального носового пристрою.

Методика. Аналітична, чисельна.

Результати. Запропонована аналітична формула оцінки енергії руйнування носового пристрою та результати прикладу його розрахунку на ЕОМ.

Наукова новизна. Запропоновані нові напрями розвитку конструктивної безпеки транспортних суден при зіткненнях.

Практична значимість. Використання результатів роботи на практиці може збільшувати конструктивну безпеку транспортних суден при зіткненнях.

Висновки. В результаті проведеної роботи була підтверджена можливість використання носового енергопоглинального пристрою та принципу векторної жорсткості різноманітних елементів носової кінцевості для суттєвого зменшення ймовірного збитку при зіткненнях суден.

Ключові слова: судно; носова кінцевість; конструктивний захист; зіткнення; енергопоглинальний пристрій.

\section{THE MAIN MATERIAL}

In spite of tremendous progress in shipbuilding and shipment in a last hundred years the ship damages are inevitable because of $80 \%$ of them are the result of sailors mistakes [1, p. 5] and collisions are one of the main kind of total damages so they are inevitable too. For this reason there are not only loss of people, vessels, cargoes but an environment is subjected by damage too. The environment is damaged not only by toxic properties and quantity of cargo but quantity of fuel and lubrication materials on board of every lost vessel (some times till 1000 tons and more). For this reason it is so important to develop all main directions of vessels construction defense when collision.

When to development of side construction defense when collision it was paid a grate attention especially during the appearance of nuclear powered vessels [2] and the requirements of MARPOL 73/78 convention state a double hull standard for oil tankers the requirements for bow construction from this position were not enough or absent. The fact is that a most part of vessels with bulbous bow (that has a tremendous specific strength and stability in comparison with construction of rammed vessel side assemblies) has it before the outline of above water part of forepeak (see fig. 1a) and reaches rammed vessel side assembly first. The result of collision with such vessel as a rule is evident - significant local deformations or hole in a side assembly of rammed vessel (depends on the value of strike kinetic energy and parameters of side assembly) and bulb construction in this situation as a rule has no any visible plastic deformations.

The presents of plastic deformations of some vessels bow part side surfaces without any collisions [3] shows that there practical resources of there parameters are exhausted (for used construction element thicknesses, materials and spacing). But at the same time the rigidity of vessel bow parts in a direction of collision strike is surplus that show the numerous examples of such accidents.

The practical analysis of transport vessels bow parts gives an opportunity to make a conclusion that the requirements for there shape and rigidity from a construction safety position are absent $[4$, p. 78$]$ in spite of the fact that most vessels were designed, build and in service in accordance with the rules of leading classification societies such as British [5] and German [6] Lloyds Register of Shipping, French Bureau Veritas [7], Russian [8] and Ukrainian [9] Register of Shipping.

In fig. 1 there are presented 3 types of vessel bow parts with different ability to consume strike energy when collision and in fig. 2 - offered bow energy consuming device [10].

Such a devise arranged in above water vessel bow part (for sure not for the high ice class vessels) can not only consume strike energy from own distruction but to encrease a total contact area that involve more details of collide vessels (that increase the consumed strike energy) and a strike time that lead to more strike energy dispersion.

The total strike kinetic energy when collision is distributed between consumed destruction energy of rammed vessel side assembly and bow part construction of strike vessel and part of total strike energy is consumed due to dispersion - including possible shifting and turning of both vessels. It is evident that it is required to develop all directions of construction defense in order to decrease the total damage when collision.

The absence of direct classification requirements to bow parts topology and rigidity on the way of possible collision strike decrease there role in a total accident balance. So in a present time the absence of such requirements makes it minimum of bow parts consumed energy when collision and there rigidity in this direction as a rule is surplus.

It should be mentioned also that bulbous construction is situate under water surface and when collision the hole in rammed vessel side assembly is appeared under water too that is more dangerous that a hole or a big deformation from the strike of above water part of ramming vessel bow.

In fig. 3 there is shown the sealing conditions of offered devise model and in fig. 4 - the load distribution in a strike moment.

In this work there is presented the calculation example of energy consuming devise that consists of rectangular steel frame (made of angle bars $200 \times 200 \times$ x 20 millimeters) with a breadth 3,6 meters, 2,8 meters 


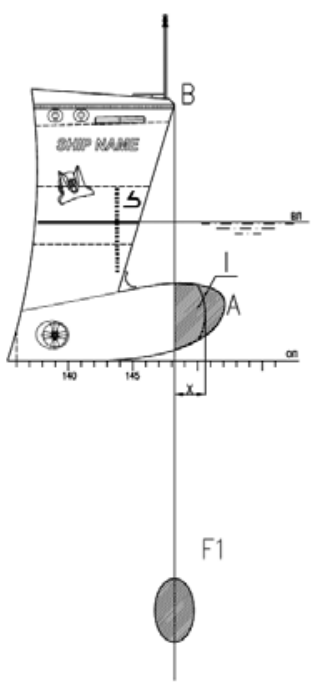

a)

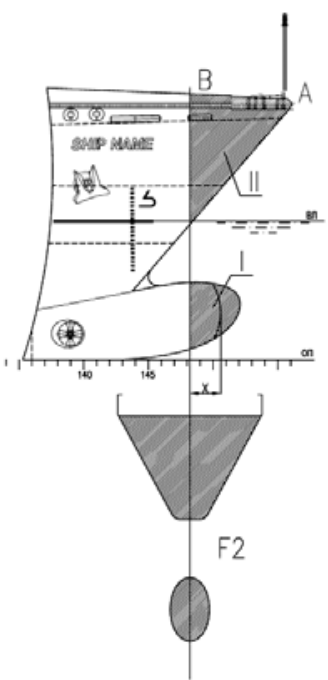

b)

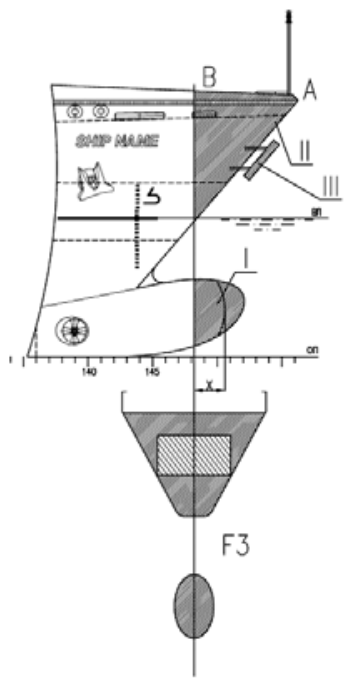

c)

Fig. 1. Types of bulbous bows from strike energy consuming position a-negative example of bulbous bow when collision; $b$ - positive example of bulbous bow when collision;

$c$ - positive example of bulbous bow when collision with energy consuming devise; $A$ - first contack point of above water bow part of rammed vessel;

$B$ - fixed final point of bow part deformation zone;

$A B$ - deformation zone of vessel bow part when collision;

$F$ - contact area.

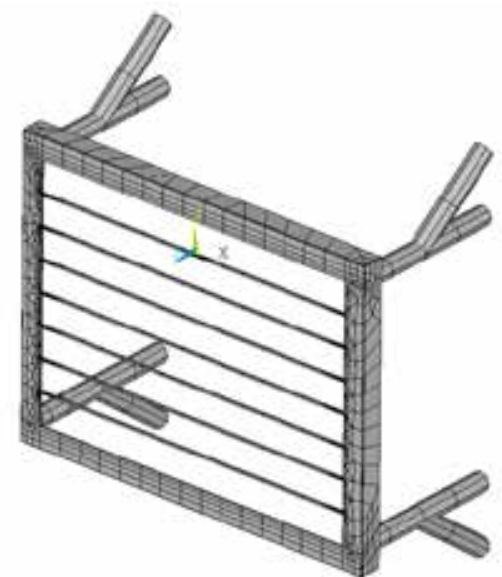

Fig. 2. The model of bow energy consuming device

height, horizontal steel ropes with 20 millimeters diameter and 4 support rods (made of circular tube elements $180 \times 10$ millimeters) with a length 1,6 meters and the same 4 intermediate supports at a total horizontal load $981 \mathrm{kn}$. The model parameters for sure can be changed.

The results of this model specialized computer program based on Finite element method are presented in fig. 5 and fig. 6.

This devise consumes a certain value of collision energy and for the expense of contact area increase of rammed vessel many additional elements such as frames, diaphragms and other are involved in to deformation and destruction process and increase the total balance of construction elements destruction energy till the

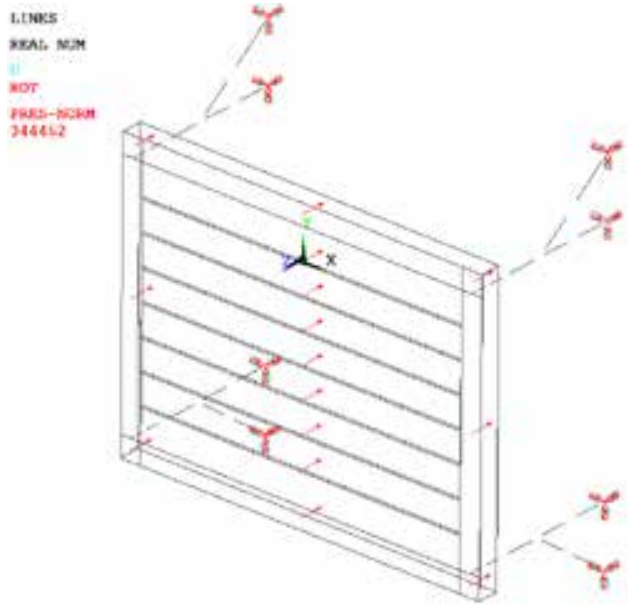

Fig. 3. The sealing conditions of devise model

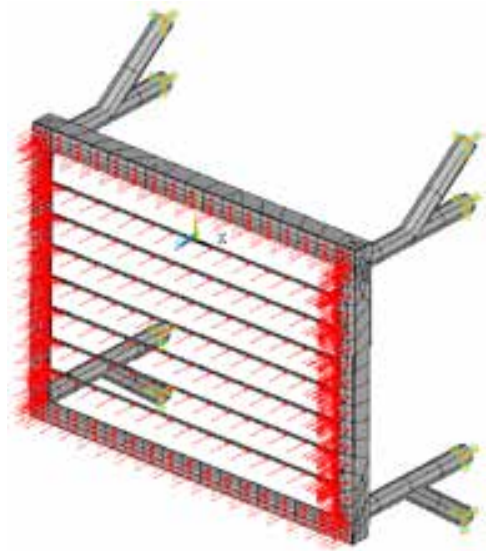

Fig. 4. Model load distribution 

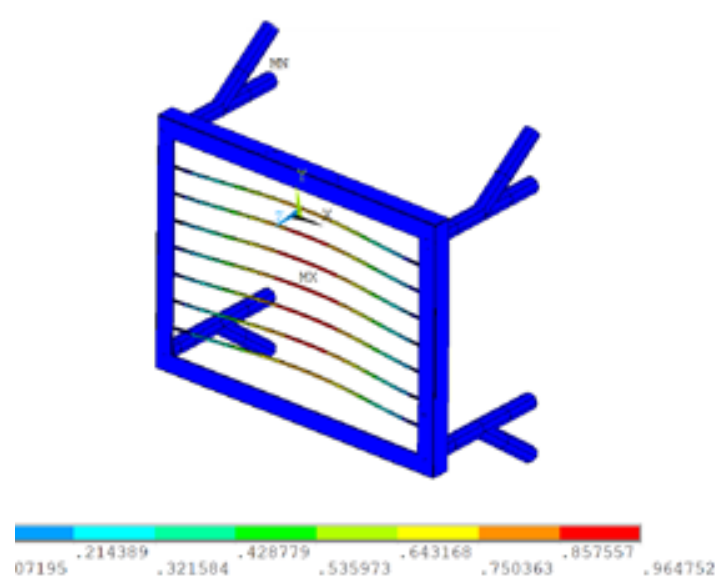

Fig. 5. Model construction elements shiftings (load $981 \mathrm{Kn}$ )

dangerous size of probable hole when a damaged compartment will be filled with outside water or leakage of dangerous cargo and other. Increase of total consumed construction elements energy means an increase of strike vessel speed required to produce a dangerous hole. It means the decrease of vessel loss or significant damage probability when collision.

It should be mentioned that parameters of this devise should be taken from support rods loss of stability as a dominant condition of devise distruction.

Then the own destruction energy of such a devise can be expressed by formular:

$$
W=\sum_{i=1}^{n} \frac{\pi^{2} E_{i} I_{i}}{\mu_{i} l_{i}^{2}} h,
$$

where $\mathrm{n}$ - number of support rods;

$E_{i}$ - Young's modulus of i-rod element;

Ii - central moment of inertia for i-rod element;

$1_{i}-$ span of $i$-rod element;

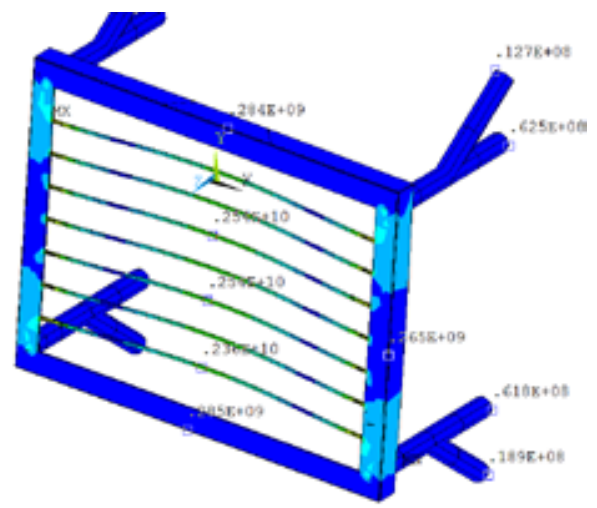

Fig. 6. Mizes stresses at model elements (load $981 \mathrm{Kn}$ )

$\mu_{\mathrm{i}}$ - sealing coefficient of i-rod element;

$\mathrm{h}$ - braking distance of energy consuming devise.

For sure sush a devise is not able to solve all construction safety problems when collision but due to own distruction energy and encrease of strike time and number and volume of involved in to deformation construction elements it is could really decrease the probable damage when such kind of accidents.

The control of bulbous construction position about above water forepeak part and there elements regidity (including some possible corrugated construction elements) in strike direction could conduce to ttis problem solution.

\section{CONCLUSIONS}

Due to results analysis it was confirmed the ability of bow energy consuming devise and vector rigidity conception for different bow construction elements to decrease the total probable damage when vessels collisions.

\section{REFERENCES}

[1] Aleksandrov M. N. (1983) Bezopasnost cheloveka na more [Human Safety at Sea]. Leninrad. Sudostroenye. [in Russian]

[2] Volkov N. N., Kodatskyi S. B. (1971) Konstruktivnye osobennosti atomnyh sudov [Construction features of nuclear-powered ships]. Leningrad. Sudostroenie. [in Russian]

[3] Barabanov N. V., Turmov, G. P. Konstrukcija korpusa morskih sudov [Hull construction of sea-going vessels]. Saint-Petersburg. Sudostroenie. [in Russian]

[4] Mihajlov B. N. (2001) Trebovanija konstruktivnoj bezopasnosti pri stolknovenijah dlja nosovyh okonechnosti sudov [Structural collision safety requirements for bow ends of ships]. Nikolaev. Zbirnyk naukovykh prats Ukrainskoho derzhavnoho morskoho tekhnichnoho universytetu, no. 5, pp. 78-79.

[5] Lloyd's Register Marine and Shipping. (2012) Retrieved from: https://www.lr.org/en/marine-shipping/

[6] Germanischer Lloyd. (2018) Retrieved from: https://www.dnv.com/

[7] Bureau Veritas Certification. (2018) Retrieved from: https://certification.bureauveritas.com/

[8] Pravila klassifikacii i postrojki morskih sudov. (2021) Rossijskij Morskoj registr sudohodstva [Russian Maritime Register of Shipping]. Chast II. Saint Petersburg. [in Russian]

[9] Rehistr sudnoplavstva Ukrainy. (2020) Pravyla klasyfikatsii ta pobudovy morskykh suden. Tom 2. Kyiv. [in Ukrainian]

[10] Mykhailov B. N., Hy Kankan. (2020) O povyshenii konstruktivnoj bezopasnosti nosovyh okonechnostej sudov pri stolknovenijah [On increasing the constructive safety of bow ends of ships in collisions]. Modern technologies of design, construction, operation and repair of ships, marine technical meansand engineering structures. Mykolayiv, Admiral Makarov National University of Shipbuilding. 


\section{СУДНОБУДУВАННЯ №3 2021}

\section{BIBLIOGRAPHY}

[1] Александров М. Н. (1983) Безопасность человека на море. Ленинград. Судостроение. 208 с.

[2] Волков Н. Н., Кодацкий С. Б. (1971.) Конструктивные особенности атомных судов. Ленинград. Судостроение. 248 с.

[3] Барабанов Н. В., Турмов Г. П. (2002) Конструкция корпуса морских судов. Санкт-Петербург. Судостроение. Т. 2.471 с.

[4] Михайлов Б. М. (2001) Требования конструктивной безопасности носовых оконечностей судов при столкновениях. Збірник наукових праць Украӥнського державного технічного університету. Миколаїв. № 5(377). С. 78-79.

[5] Lloyd's Register Marine and Shipping. (2012) URL: https://www.lr.org/en/marine-shipping/ (дата звернення: 01.09.2021).

[6] Germanischer Lloyd. (2018). URL: https://www.dnv.com/ (дата звернення: 01.09.2021).

[7] Bureau Veritas Certification. (2018). URL: https://certification.bureauveritas.com/(дата звернення: 01.09.2021).

[8] Правила классификации и постройки морских судов. (2021) Российский Морской регистр судоходства. Часть II. Санкт-Петербург. 326 с.

[9] Регістр судноплавства України. (2020) Правила класифікації та побудови морських суден. Том 2. Київ. 792 с.

[10] Михайлов, Б. М., Ги, Канкан. (2020) О повышении конструктивной безопасности носовых оконечностей судов при столкновениях. Сучасні технологї̈ проєктування, побудови, експлуатачії та ремонту морських технічних засобів і інженерних споруд : матеріали межд. науч.-техн. конф., 20-21 травня, 2020. Миколаїв, НУК.

(C) Михайлов Б. М. Дата надходження статті до редакції: 10.09.2021 p. Дата затвердження статті до друку: 27.09.2021 р. 